\title{
SEROPREVALENCE OF HEPATITIS C VIRUS AMONGST PATIENTS ATTENDING FIVE SELECTED HOSPITALS IN NIGER STATE, NIGERIA
}

Iduh M.U, Kuta F.A, ${ }^{l}$ Abalaka M.E, ${ }^{1}$ Shitu K.O. ${ }^{2}$

Department of Medical Microbiology, School of Medical Laboratory Science,Usmanu Danfodiyo University, Sokoto, Nigeria.

${ }^{1}$ Department of Microbiology and ${ }^{2}$ Department of Biochemistry, School of Life Sciences, Federal University of Technology, Minna, Nigeria.

*Corresponding Author: Iduh M.U, Department of Medical Microbiology, School of Medical Laboratory Science/College of Health Sciences, Usmanu Danfodiyo University, Sokoto, Nigeria.

Published: November $23^{\text {rd }} 2018$

\begin{abstract}
The aim of this study was to determine the prevalence of hepatitis $C$ virus amongst patients attending five selected hospitals in Niger State. A total of 565 blood samples were screened using enzyme linked immunosorbent assay (ELISA) test kit for anti-hepatitis $C$ virus (HCV). Structured questionnaires were administered to participants and data were analyzed using SPSS Version 19.0 with $P<0.05$ as the level of significance. HCV infection was detected in 44 out of the 565 blood samples examined. The overall prevalence was $7.8 \%$ with male $4.8 \%$ and female $3.0 \%$ respectively. Participants within age group 31-40 years had the highest prevalence $(11.5 \%), 41-50$ years followed closely with $11.0 \%$, while $>1-10$ years, $21-30$ years, $\geq 60$ years and above, 51-60 years and 11-20 years had 9.1\%, 8.3\%, 4.0\%, 3.5\% and 2.3\% in that order. All the demographic variables and risk factors considered in this study were not significantly associated with anti- HCV seropositives. The prevalence of HCV infection in Niger State was not high when compared with similar studies. However, compulsory public awareness campaigns against HCV infection and prevention programmes should be intensified.
\end{abstract}

Keywords: Blood, HCV, Nigeria, Prevalence, Risk Factors

\section{Introduction}

Hepatitis $C$ virus (HCV) is a small (55-65 nm in size), enveloped, positive-sense single-stranded RNA virus of the family Flaviviridae which belongs to the genus Hepacivirus. HCV was considered to be the only member of this genus. However, another member of this genus has been discovered in dogs canine hepacivirus. ${ }^{1}$ Several additional viruses in the genus have been described in bats and rodents. ${ }^{1}$ According to the world health organization there are 130-170 million people infected with the hepatitis $\mathrm{C}$ virus. Hepatitis $C$ virus is the cause of hepatitis $\mathrm{C}$ and some cancer lymphomas in humans. ${ }^{2,3}$ The hepatitis $C$ virus particle consists of a core of genetic material (RNA), surrounded by an icosahedral protective shell of protein, and further encased in a lipid (fatty) envelope of cellular origin. Two viral envelope glycoproteins, E1 and E2, are embedded in the lipid envelope. ${ }^{4,5}$ The hepatitis $C$ virus species is classified into seven genotypes (1-7) with several subtypes within each genotype. Subtypes are further broken down into quasispecies based on their genetic diversity. Subtypes $1 \mathrm{a}$ and $1 \mathrm{~b}$ are found worldwide and cause $60 \%$ of all cases of HCV infections. ${ }^{6,7}$ Genotypes 1 and 4 are less responsive to interferon-based treatment than are the other genotypes (2, 3, 5 and 6). The duration of standard interferon-based therapy for genotypes 1 and 4 is 48 weeks, whereas treatment for genotypes 2 and 3 is completed in 24 weeks. ${ }^{8,9}$ Hepatitis $C$ virus is predominantly a blood-borne virus, with very low risk of sexual or vertical transmission. Because of this mode of spread the key groups at risk are intravenous drug users (IDUs), people who are transfused with blood, recipients of blood products and sometimes patients on haemodialysis. ${ }^{10,7}$ Common setting for transmission of $\mathrm{HCV}$ is also intra-hospital (nosocomial) transmission, when practices of hygiene and sterilization are not correctly followed in the clinic. ${ }^{11,12}$ A number of cultural or ritual practices 
have been proposed as a potential historical mode of spread for hepatitis $C$ virus, including circumcision, genital mutilation, ritual scarification, traditional tattooing and acupuncture. It has also been argued that given the extremely prolonged periods of persistence of HCV in humans, even very low and undetectable rates of mechanical transmission via biting insects may be sufficient to maintain endemic infection in the tropic, where people receive large number of insect bites. $^{6,3}$

Most people (80\%) with acute HCV infection have no symptoms. ${ }^{13}$ If symptoms occur, they may include loss of appetite, abdominal pain, fatigue, nausea, dark urine, and jaundice. Of those who develop chronic $\mathrm{HCV}$ infection, the most common symptom is fatigue. $^{11,9}$ Severe liver disease develops in approximately $10 \%-20 \%$ of chronically infected people, but progression to end-stage liver disease is slow and typically does not occur until $\geq 20$ years after infection. This progression is often clinically silent until late in the course of disease, and in the absence of HCV testing, most people are unaware of their infection. Nonetheless, HCV is a major cause of cirrhosis and hepatocellular cancer and it is the leading reason for liver transplantation in the United States and other parts of the world. ${ }^{10,14}$

The epidemiology of HCV infection in Nigeria is not well understood. Most studies of hepatitis $C$ in Nigeria have focused on serological characterization of selected population groups, e.g. prison inmates, patients with diabetes mellitus, blood donors, HIVinfected persons, patients with chronic renal failure and those with sickle cell anaemia, for whom risk for $\mathrm{HCV}$ infection in urban areas of Nigeria is variable. Previous studies ${ }^{15}$ established a broad HCVseroprevalence rate, ranging from $1.9 \%$ among pregnant women in Benin City to $14.5 \%$ among apparently healthy individuals with a family history of diabetes in Plateau State ${ }^{16,17}$ or among HIV-positive patients in Lagos. ${ }^{18,19} \mathrm{HCV}$ infections have been shown to play a significant role in the aetiology of chronic liver disease and Hepatocellular carcinoma (HCC) in Nigeria. ${ }^{20,21}$ This study was designed to determine the seroprevalence of $\mathrm{HCV}$, probable demographic variables and risk factors amongst the participants in the study area.

\section{Materials and Methods}

\section{Description of the study area}

Niger State is located in North Central Nigeria and has Minna as its capital. The State lies on latitude $3.20^{\circ}$ East and longitude $11.30^{\circ}$ North. It is $150 \mathrm{~km}$ away from Abuja the Federal capital. Two of Nigeria's major hydroelectric power stations, the Kainji and the Shiroro Dams, are located in Niger State. Niger state has a population of 3,950,249 in 2006 population census. There are three most pronounced ethnic groups which are Nupe, Gbagyi and Hausa. The major farm products cultivated by these ethnic groups are rice, yam, millet, etc.

\section{Study design}

The study was hospital-based and covered the three senatorial zones in Niger State. The proposed hospitals where samples were collected from are General Hospital Minna (GHM), General Hospital Kontagora (GHK), Umaru Sanda Ndayako Hospital Bida (USNHB), General Hospital Wushishi (GHW) and General Hospital Suleja (GHS). Five hundred and sixty-five (565) blood samples were collected from patients in the phlebotomy section of the hospitals mentioned above (113 from each hospital). The choice of the hospitals was purposeful. Ethical clearance was obtained from the ethical committee of each of the hospitals. A structured questionnaire and consent form were designed and administered, in order to obtain demographic information, characteristics, personal and behavioural risk factors (such as age, sex, family type, history of blood transfusion, education, occupation, etc,). The laboratory methodology employed was Enzyme-linked immunosorbent assay (ELISA).

\section{Ethical approval}

Ethical approval was obtained from Research and Ethics Committee of the five hospitals mentioned above. Informed consent of each participant was obtained prior to sample collection. Confidentiality was maintained and risk factors explained. The results obtained from data collected were protected.

\section{Sample collection.}

Samples were collected from the months of FebruaryApril, 2017. A total of 565 blood samples were aseptically collected through the veins using sterile 5 $\mathrm{ml}$ syringe and needle, and introduced into sterile test tube and allowed to cloth. ${ }^{22}$ The samples were 
respectively centrifuged at $2000 \mathrm{rpm}$ for 2 minutes and the serum separated. Separated sera were stored in cryovials in the refrigerator $\left(4^{0} \mathrm{C}\right)$ for further analysis. All necessary precautions were taken to guide against interference that could negatively affect the result. The services of other Medical Laboratory Scientists were employed during analysis of the samples.

\section{ELISA Procedure for detection of HCV Antibodies}

The HCV antibodies were detected using qualitative RecombiLISA HCV ELISA kit manufactured by CTK Biotech, Inc., San Diedgo, USA. All reagents and controls (positive and negative) were brought to room temperature. The concentrated washing buffer was diluted 30 fold with distilled water. Well A1 was blank; A2 and A3 of the microtitre plates were negative controls, wells A4 and A5 were positive controls and the remaining wells were used for samples. One hundred microlitre $(100 \mu \mathrm{l})$ of positive \& negative controls were added into appropriately labelled wells of the microwells plate. One hundred microlitre $(100 \mu \mathrm{l})$ of sample diluent was added to all the test wells. Ten microlitre $(10 \mu \mathrm{l})$ of test samples was added into each test well and mix thoroughly by gentle rocking for twenty seconds. Separate disposable pipette tips were used for each specimen, negative and positive controls to avoid crosscontamination. The plates were covered with a sealant and incubated for $30 \mathrm{~min}$ at $37^{\circ} \mathrm{C}$. At the end of the incubation, the mixture was removed by emptying the solution into a waste container. Each well was filled with diluted wash buffer (Phosphate Buffered Saline containing Tween-20 as a detergent) and shaken gently for 20 seconds. The wash solution was completely discarded and the plate tapped on absorbent paper to remove remaining liquids. The plate was washed four more times. One hundred microlitre of horse radish peroxidase-conjugate was added to each well except the blank. The plates were covered with new sealant and incubated for 20 minutes at $37^{\circ} \mathrm{C}$. The wells were washed 5 times with diluted wash buffer. Fifty microlitre of Tetramethylbenzidine (TMB) substrate A (Chromogen) and TMB substrate B solutions were added into each well including the blank and mixed by tapping the plate gently. The plates were further incubated at $37^{\circ} \mathrm{C}$ for 10 minutes in the dark. The enzymatic reaction between the Chromogen A and $\mathrm{B}$ solutions produced a blue colour in the positive control and positive sample wells. Fifty microlitre of $0.5 \mathrm{M}$ Tetraoxosulphate (VI) acids (stop solution) was added into each well and mixed by tapping the plates gently. Intensive yellow colour developed in positive control and HCV positive wells. The optical Density (OD) was read at $450 \mathrm{~nm}$ wavelengths within 15minutes of stopping the reaction using GF-M3000 microplate reader and results were read according to the manufacturer's manual.

\section{Interpretation of ELISA Results}

(a) Set up of the cut-off value

The cut-off value $=0.15+\mathrm{N}$

$\mathrm{N}$ : mean OD of the negative control. 0.05 was usually used for the calculation of the cut-off value if $\mathrm{N}$ is less than 0.05 (manual instructions).

(b) Calculation of OD specimen ratio

Specimen OD ratio was calculated by dividing specimen OD by the cut-off value as follows: Specimen OD ratio = specimen OD/ Cut-off value

\section{(c) Assay validation}

The mean $\mathrm{OD}$ value of the $\mathrm{HCV} \mathrm{Ab}$ positive controls $=\geq 0.80$

The mean OD value of the $\mathrm{HCV}$ Ab negative controls $=\leq 0.10$

(d) Interpretation of the results

Specimen OD $\geq 1.00=$ Positive

Specimen OD $<1.00=$ Negative

\section{Statistical analysis}

Data was analyzed using Statistical Package for the Social Sciences (SPSS) version 19 software (SPSS Inc., Chicago, IL, USA). Pearson chi-squares were calculated at a 95\% confidence interval. $\mathrm{P}$ values < 0.05 were considered statistically significant.

\section{Results}

The prevalence of Hepatitis $C$ virus among patients attending the five hospitals (GHM, GHS, GHK, GHW and USNHB) showed that out of five hundred and sixty five serum samples screened, 44(7.8\%) were positive. $27(9.4 \%)$ of this were male while $17(6.1 \%)$ were female. The prevalence of HCV among males was more compare to their female's counterpart but no significant difference $\left(\mathrm{X}^{2}=2.204, P=0.1377\right)$ was statistically observed between the prevalence of the virus and the gender. This means the rate of infection is not associated with sex (Table 1).

Table 2 shows the distribution of HCV according to age of patients in various hospitals. Those between $31-40$ years had higher prevalence of $11.5 \%$, followed 
by $41-50$ years $(11.0 \%),>1-10$ years $(9.0 \%), 21-$ 30years $(8.3 \%),>61$ years $(4.0 \%) 51-60$ years $(3.5 \%)$ and 11-20 years (2.3\%). The HCV infection among these age groups was not statistically significant $\left(\mathrm{X}^{2}=\right.$ $10.387, P=0.1092$ ).

The association between some demographic factors and the viral infections among participants is shown on Table 3. The incidence of HCV based on marital status in the hospitals showed that married participants have higher prevalence of $31(9.7 \%)$ than single $13(5.3 \%)$. There was no statistical significant difference $\left(\mathrm{X}^{2}=3.895, P=0.0484\right)$ between the prevalence of the virus and marital status of the patients.

There was no statistically significant association $\left(\mathrm{X}^{2}=\right.$ $0.1479, P=0.3043$ ) between the viral infections and polygamy. The distribution of HCV based on family type in the hospitals indicated that polygamy has the highest prevalence of $29(8.8 \%)$ whereas monogamy had $15(6.4 \%)$.

The distribution of HCV based on educational status showed that, $17(11.9 \%)$ prevalence was found among patients that had no education (NO) while those who had Arabic (AR), primary (PR), secondary (SE) and tertiary (TE) education have 13(9.6\%), 2(6.9\%), $3(2.6 \%)$ and $9(6.4 \%)$ respectively. A non-statistically significant difference was observed between antiHCV and educational status $\left(\mathrm{X}^{2}=8.851, P=0.0649\right)$.

No statistical significant difference was recorded between the prevalence of the virus and the occupational status of the studied population $\left(\mathrm{X}^{2}=\right.$ 4.040, $P=0.1327)$. The distribution of $\mathrm{HCV}$ according to occupation showed that the selfemployed had a higher prevalence of $21(7.8 \%)$ while unemployed and public servants have $13(11.8 \%)$ and $10(5.3 \%)$ respectively. The distribution of HCV based on settlement in the various health facilities showed that $29(8.9 \%)$ prevalence was found among patients in rural areas while those in urban had 15(6.3\%). The incidence of $\mathrm{HCV}$ infection among the patients in the urban and rural areas was not statistically significant $\left(\mathrm{X}^{2}=1.318, P=0.2510\right)$. The result of the analysis of seroprevalence of $\mathrm{HCV}$ in relation to possible risk factors among the participants is shown on Table 4. The rate of HCV infection was not dependent on the history of blood transfusion $\left(\mathrm{X}^{2}=0.0566, P=\right.$ 0.8120 ). Patients with previous history of blood transfusion had the highest prevalence of $7(8.4 \%)$ and those without previous history have $37(7.7 \%)$.

Patients with no history of jaundice had prevalence rate of $44(7.9 \%)$ as against $0(0.0 \%)$ found among those that have previous history. The incidence of $\mathrm{HCV}$ infection is not associated with history of jaundice $\left(\mathrm{X}^{2}=0.5986, P=0.4391\right)$.

Similarly, participants with family history of hepatitis have no recorded prevalence rate of the infection compare to those who do not have $(7.9 \%)$. The distribution of infection was not dependent on family history of hepatitis $\left(\mathrm{X}^{2}=0.5121, P=0.4742\right)$.

No statistically significant association $\left(X^{2}=0.0213, P\right.$ $=0.8840$ ) was observed between HCV prevalence and patients with tattoo/body piercing. The highest HCV prevalence of $8.0 \%$ was found among those who have tattoo/body piercing while $7.7 \%$ was obtained among the patients that did not have. The distribution of HCV in relation to alcohol intake in various hospitals showed a prevalence of $2(8.7 \%)$ for participants who consumed alcohol as against $42(7.7 \%)$ that do not. Statistically, there was no significant difference between the prevalence of the virus and alcohol intake $\left(\mathrm{X}^{2}=0.0275, P=0.8682\right)$.Infection of $\mathrm{HCV}$ among patients involved in cigarette consumption was not statistically significant $\left(\mathrm{X}^{2}=2.960, P=0.0854\right)$. A prevalence rate of $44(7.9 \%)$ was recorded among patients who do not smoke cigarette while no prevalence was observed among those who smoke.

Sharing of clothes was not associated with $\mathrm{HCV}$ infection $\left(\mathrm{X}^{2}=0.4220, P=0.5160\right)$. A prevalence rate of $7.9 \%$ was obtained among patients that do not share clothes and $0.0 \%$ in those that shared.

The distribution of HCV infection among patients on previous history of surgery indicated that those without previous history have prevalence of $44(7.9 \%)$ while those with history had none $(0.0 \%)$. However, there was no significant difference statistically observed between the prevalence of the virus and surgery before $\left(\mathrm{X}^{2}=0.7724, P=0.3795\right)$.

Table 1: Distribution of HCV among patients in five hospitals based on sex

\begin{tabular}{|c|c|c|c|c|c|c|}
\hline & \multicolumn{3}{|c|}{ Male } & \multicolumn{3}{|c|}{ Female } \\
\hline Hospital & NSS & $\begin{array}{l}\text { NPS } \\
(\%)\end{array}$ & NNS (\%) & NSS & $\begin{array}{l}\text { NPS } \\
(\%)\end{array}$ & NNS (\%) \\
\hline GHM & 59 & $1(1.7)$ & $58(98.3)$ & 54 & $4(7.4)$ & $50(92.6)$ \\
\hline GHS & 61 & $2(3.3)$ & $2(3.3)$ & 52 & $0(0.0)$ & $52(100)$ \\
\hline GHK & 55 & $12(21.8)$ & $43(78.2)$ & 58 & $2(3.4)$ & $56(96.6)$ \\
\hline GHW & 60 & $11(18.3)$ & $49(81.7)$ & 53 & $4(7.5)$ & $49(92.5)$ \\
\hline USNHB & 51 & $1(2.0)$ & $50(98.0)$ & 62 & $7(11.3)$ & $55(88.7)$ \\
\hline Total & 286 & $27(9.4)$ & $259(90.6)$ & 279 & 17(6.1) & $262(93.9)$ \\
\hline $\begin{array}{l}\chi^{2}=2.204, \\
\text { Key: GHM } \\
\text { Kontogora, } \\
\text { HCV }=\text { Hep } \\
N N S=N u m\end{array}$ & 0.137 & $D(P<0.05)$ & & & & $\begin{array}{l}\text { ral Hospital } \\
\text { spital Bida, } \\
\text { ive samples, }\end{array}$ \\
\hline
\end{tabular}


Table 2: Distribution of $\mathrm{HCV}$ in relation to age of patients in five hospitals

\begin{tabular}{|c|c|c|c|c|c|c|c|c|c|c|c|c|c|c|c|c|c|c|}
\hline \multicolumn{19}{|c|}{ HOSP } \\
\hline & & GHM & & & GHS & & & GHK & & & GHW & & & USNHB & & & Total & \\
\hline $\mathrm{AG}$ & NSS & NPS(\%) & NNS (\%) & NSS & NPS $(\%$ & NNS (\%) & NSS & NPS(\%) & NNS (\%) & NSS & NPS(\%) & NNS (\%) & NSS & NPS (\%) & NNS (\%) & NSS & NPS (\%) & NNS (\%) \\
\hline $1-10$ & 4 & $0(0.0)$ & $4(100)$ & 9 & $0(0.0)$ & $9(100)$ & 2 & $0(0.0)$ & $2(100)$ & 4 & $2(50)$ & $2(50)$ & 3 & $0(0.0)$ & $3(100)$ & 22 & $2(9.1)$ & $20(90.9)$ \\
\hline $11-20$ & 18 & $0(0.0)$ & $18(100)$ & 25 & $0(0.0)$ & $25(100)$ & 11 & $1(9.1)$ & $10(90.9)$ & 19 & $0(0.0)$ & $19(100)$ & 15 & $1(6.7)$ & $14(93.3)$ & 88 & $2(2.3)$ & $86(97.7)$ \\
\hline $21-30$ & 16 & $0(0.0)$ & $16(100)$ & 25 & $1(4.0)$ & $24(96.0)$ & 19 & $2(10.5)$ & $17(89.5)$ & 17 & $3(23.1)$ & $14(76.9)$ & 32 & $3(9.4)$ & $29(90.6)$ & 109 & $9(8.3)$ & $100(91.7)$ \\
\hline $31-40$ & 30 & $4(13.3)$ & $26(86.7)$ & 20 & 0.0 & $20(100)$ & 34 & $5(14.3)$ & $29(85.7)$ & 25 & $5(20.0)$ & $20(80.0)$ & 21 & $1(4.8)$ & $20(95.2)$ & 130 & $15(11.5)$ & 115 (98.5) \\
\hline $41-50$ & 16 & $1(6.3)$ & $15(93.7)$ & 19 & 0.0 & $19(100)$ & 29 & $5(17.2)$ & $24(82.8)$ & 19 & $4(21.1)$ & $15(78.9)$ & 26 & $2(7.7)$ & $24(92.3)$ & 109 & $12(11.0)$ & $97(89.0)$ \\
\hline $51-60$ & 12 & $0(0.0)$ & $12(100)$ & 7 & 0.0 & $7(100)$ & 13 & $1(7.7)$ & $12(92.3)$ & 16 & $1(6.3)$ & $15(93.7)$ & 9 & $15(93.7)$ & $9(100)$ & 57 & $2(3.5)$ & $55(96.5)$ \\
\hline$\geq 61$ & 17 & $0(0.0)$ & $17(100)$ & 8 & $1(12.5)$ & $7(87.5)$ & 5 & $0(0.0)$ & $5(100)$ & 13 & $0(0.0)$ & $13(100)$ & 7 & $1(14.3)$ & $6(85.7)$ & 50 & $2(4.0)$ & $48(96.0)$ \\
\hline Total & 113 & $5(4.4)$ & $108(95.6)$ & 113 & $2(1.8)$ & $111(98.2)$ & 113 & $14(12.4)$ & $99(87.6)$ & 113 & $15(13.2)$ & $98(86.7)$ & 113 & $8(7.1)$ & $105(92.9)$ & 565 & $44(7.8)$ & $521(92.2)$ \\
\hline
\end{tabular}

$\chi^{2}=10.387, P=0.1092, S D(P<0.05)$

Key: $H_{O S P}=$ Hospital, GHM = General Hospital Minna, GHS = General Hospital Suleja, GHK = General Hospital Kontogora, GHW = General Hospital Wushishi, USNHB =Umaru Sanda Ndayako Hospital Bida, HCV = Hepatitis c virus, NSS = Number of samples screened, $N P S=$ Number of positive samples, NNS = Number of negative samples, $A G=$ Age group, $S D=$ Significant difference

Table 3: Relationship between HCV infection and Demographic characteristics of the patients

\begin{tabular}{|c|c|c|c|c|}
\hline Demographic characteristics & NSS & NPS & NNS & P-Value \\
\hline \multicolumn{5}{|l|}{ Sex } \\
\hline Male & $286(50.6 \%)$ & $27(4.8 \%)$ & $259(45.8 \%)$ & \multirow[t]{2}{*}{0.1377} \\
\hline Female & $279(49.4 \%)$ & $17(3.0 \%)$ & $262(46.4 \%)$ & \\
\hline \multicolumn{5}{|l|}{ Age groups (years) } \\
\hline$<1-10$ & $22(3.9 \%)$ & $2(0.4 \%)$ & $20(3.5 \%)$ & \multirow{7}{*}{0.1092} \\
\hline $11-20$ & $88(15.6 \%)$ & $2(0.4 \%)$ & $86(15.2 \%)$ & \\
\hline $21-30$ & $109(19.3 \%)$ & $9(1.5 \%)$ & $100(17.7 \%)$ & \\
\hline $31-40$ & $130(23.0 \%)$ & $15(2.6 \%)$ & $115(20.4 \%)$ & \\
\hline $41-50$ & $109(19.3 \%)$ & $12(2.1 \%)$ & $97(17.2 \%)$ & \\
\hline $51-60$ & $57(10.1 \%)$ & $2(0.4 \%)$ & $55(9.7 \%)$ & \\
\hline$\geq 61$ & $50(8.8 \%)$ & $2(0.4 \%)$ & $48(8.5 \%)$ & \\
\hline \multicolumn{5}{|l|}{ Marital status } \\
\hline Married & $318(56.3 \%)$ & $31(5.5 \%)$ & $287(50.8 \%)$ & \multirow[t]{2}{*}{0.0484} \\
\hline Single & $247(43.7 \%)$ & $13(2.3 \%)$ & $234(41.4 \%)$ & \\
\hline \multicolumn{5}{|l|}{ Family type } \\
\hline Monogamy & 234(41.4) & $15(2.7 \%)$ & $219(38.8 \%)$ & \multirow[t]{2}{*}{0.3043} \\
\hline Polygamy & $331(58.6)$ & $29(5.1 \%)$ & $302(53.5 \%)$ & \\
\hline \multicolumn{5}{|l|}{ Educational qualification } \\
\hline None & $143(25.3 \%)$ & $17(11.9 \%)$ & $126(22.3 \%)$ & \multirow{5}{*}{0.0649} \\
\hline Arabic & $135(23.9 \%)$ & $13(9.6 \%)$ & $122(21.6 \%)$ & \\
\hline Primary & $29(5.1 \%)$ & $2(6.9 \%)$ & $27(4.8 \%)$ & \\
\hline Secondary & $117(20.7 \%)$ & $3(2.6 \%)$ & $114(20.2 \%)$ & \\
\hline Tertiary & $141(25.0 \%)$ & $9(6.4 \%)$ & $132(23.4 \%\}$ & \\
\hline \multicolumn{5}{|l|}{ Occupation } \\
\hline Public servant & $187(33.1 \%)$ & $10(1.8 \%)$ & $177(31.3 \%)$ & \multirow{3}{*}{0.1327} \\
\hline Unemployed & $110(19.5 \%)$ & $13(2.3 \%)$ & $97(17.2 \%)$ & \\
\hline Self-employed & $268(47.4 \%)$ & $21(3.7 \%)$ & $247(43.7 \%)$ & \\
\hline \multicolumn{5}{|l|}{ Settlement } \\
\hline Urban & $239(42.3 \%)$ & $15(2.7 \%)$ & $224(39.6 \%)$ & \multirow[t]{2}{*}{0.2510} \\
\hline Rural & $326(57.7 \%)$ & $29(5.1 \%)$ & $297(52.6 \%)$ & \\
\hline
\end{tabular}

Key: NSS $=$ Number of sample screened, $N P S=$ Number of positive samples, NNS $=$ Number of negative samples 
Table 4: Relationship between HCV infection and the predisposing risk factors.

\begin{tabular}{lllll}
\hline Possible risk factors & NSS & NPS & NNS & P- Value \\
\hline $\begin{array}{l}\text { Blood transfusion } \\
\text { Yes }\end{array}$ & $83(14.7 \%)$ & $7(1.2 \%)$ & $76(13.5 \%)$ & 0.8120 \\
No & $482(85.3 \%)$ & $37(6.6 \%)$ & $445(78.7 \%)$ & \\
\hline $\begin{array}{l}\text { History of jaundice } \\
\text { Yes }\end{array}$ & $7(1.2 \%)$ & $0(0.0 \%)$ & $7(1.2 \%)$ & 0.4391 \\
No & $558(98.8 \%)$ & $44(7.8 \%)$ & $514(91.0 \%)$ & \\
\hline Family history of & & & & \\
hepatitis & & & & \\
Yes & $6(1.1 \%)$ & $0(0.0 \%)$ & $6(1.1 \%)$ & 0.4742 \\
No & $559(98.9 \%)$ & $44(7.8 \%)$ & $515(91.1 \%)$ & \\
\hline Tattoo/body piercing & & & & \\
Yes & $187(33.1 \%)$ & $15(2.7 \%)$ & $172(30.4 \%)$ & 0.8840 \\
No & $378(66.9 \%)$ & $29(5.1 \%)$ & $349(61.8 \%)$ & \\
\hline Alcohol intake & & & & \\
Yes & $23(4.1 \%)$ & $2(0.4 \%)$ & $21(3.7 \%)$ & 0.8682 \\
No & $542(95.9 \%)$ & $42(7.4 \%)$ & $500(88.5 \%)$ & \\
\hline Cigarette smoking & & & & \\
Yes & $33(5.8 \%)$ & $0(0.0 \%)$ & $33(5.8 \%)$ & 0.0854 \\
No & $532(94.2 \%)$ & $44(7.8 \%)$ & $488(86.4 \%)$ & \\
\hline Surgery before & & & \\
Yes & $9(1.6 \%)$ & $0(0.0 \%)$ & $9(1.6 \%)$ & 0.3795 \\
No & $556(98.4 \%)$ & $44(7.8 \%)$ & $512(90.6 \%)$ & \\
\hline
\end{tabular}

Key: NSS = Number of sample screened, NPS = Number of positive samples, NNS = Number of negative samples

\section{Discussion}

The seroprevalence of hepatitis $C$ virus among patients attending the five selected hospitals was analyzed and the result was presented. The prevalence rate of $7.8 \%$ obtained in this study is regarded as high defined by the HCV severity rates of $<1.5 \%=10 w$, $1.5-3.5 \%=$ moderate and $\geq 3.5 \%=$ high. $^{23,}{ }^{24}$ It is higher than $5.0 \%$ obtained among blood donors in Port Harcourt, ${ }^{25} 1.7 \%$ obtained in pregnant women in Ibadan $^{19}, 1.0 \%$ in students attending University of Maiduguri Medical Centre ${ }^{26}$ and $6.8 \%$ in Jos metropolis. ${ }^{27}$ Similarly, it was also higher compared to some studies from other parts of the world. A prevalence of $3.5 \%$ was reported in Sudan, ${ }^{3} 1.6 \%$ in Czech Republic ${ }^{9}$ and $0.42 \%$ in Iran. ${ }^{13}$ This finding is similar to the $7.7 \% \mathrm{HCV}$ rate reported by Sheyin et $a l,{ }^{28}$ and the $7.0 \%$ reported by Bigwan et $a l,{ }^{29}$ Contrary to this finding, higher $\mathrm{HCV}$ prevalence rate were reported previously. These includes $24.2 \%{ }^{12}$ reported in people attending a voluntary screening centre in Masaka, Nasarawa State, $11.5 \%{ }^{30}$ among students in Mubi, Nigeria and $16.0 \%{ }^{14}$ in Rwanda military hospital. The variation noticed in the prevalence of $\mathrm{HCV}$ in this study and the studies in different regions may be due to the differences in the socio-cultural practices, environmental factors, the mode of transmission, lack of awareness on the risk factors associated with $\mathrm{HCV}$, religious beliefs and the sample size used in the various studies from the different parts of the country.
There was no significant association between gender and $\mathrm{HCV}$ infection in this finding although males recorded a higher seroprevalence rate of $9.4 \%$ against females $6.1 \%$. This is in agreement with the results of Waje et al. ${ }^{31}$ in a similar study in Kaduna who reported that males had higher prevalence $(10.5 \%)$ than females $(2.1 \%)$. Abdel Salam et $a l,{ }^{3}$ in a study in Czech Republic also reported that males had the highest seroprevalence of $1.5 \%$ compare to females $0.39 \%$. However, Abiodun et $a l^{32}$ and Isa et $a l^{21}$ reported a higher prevalence in females than males in Ogbomoso, South-western Nigeria and Maiduguri respectively. The finding in this study reveals that gender did not show any statistical significant association with the seroprevalence of hepatitis $\mathrm{C}$ virus. This could be due to a reason that both the males and females lived in the same environment and are involved in virtually the same activities or shared the same facilities that can predispose them to the infection. This shows that gender differences cannot be used as a determinant factor for the transmission of the viral infection in the study.

In this study, patients between the ages of $31-40$ years $(11.5 \%)$ recorded the highest prevalence rate of HCV which suggests that individuals within this age group are more exposed to the virus than persons in other age groups. This could probably be attributed to the active lifestyles associated with individuals within this age group. This was in contrast to observations of Janet ${ }^{27}$ and Pennap et al, ${ }^{12}$ whom reported that high prevalence was found among patients aged 25-34 years and 21 -30 years respectively. However, Parimal et $a l,{ }^{5}$ reported a higher prevalence of $\mathrm{HCV}$ among aged $\geq 50$ years and above in India. The high prevalence among children (9.1\%) may suggest vertical as well as horizontal transmission especially as the virus is not vaccine preventable. Age contributes insignificantly to hepatitis $\mathrm{C}$ positivity. All persons become infected when expose to the virus in spite of their age.

Marital status was found to be a significant risk factor in this study; among the patients the married had the highest prevalence rate of $\mathrm{HCV}$ infection $(9.7 \%)$ compare to the single (5.3\%). This could be due to close person-person contact with infected spouse as the infection can be transmitted through body fluids and close contact. ${ }^{27}$ Positive family cases could have resulted to the highest prevalent $\mathrm{HCV}$ recorded among the married while that observed among the singles could be related to active and risky lifestyles of youthful exuberance leading to exposure to the virus. 
This finding agrees with Waje et $a l^{31}$ and Pennap et $a l,{ }^{33}$ whom found that married participants had more $\mathrm{HCV}$ infection than the singles. However, this disagrees with a previous result of $3.7 \%$ observed in singles compare to $0.9 \%$ among married patients in Sokoto, Nigeria. ${ }^{21}$ These differences in trend could be due to place of residence and different exposures indicating all persons could contract the infection when predispose to the virus regardless of marital status. $^{25}$

There was no significant association between family type and HCV infection in this study, although polygamy have the highest prevalence of $8.8 \%$ against monogamy $6.4 \%$. Similar to findings reported by Abiodun et $a l^{32}$ sexual behavioural risk factors such as having sex early in life and multiple sexual partners were not significant predictors of $\mathrm{HCV}$ contraction in this study. The rate of transmission of $\mathrm{HCV}$ infection through sexual intercourse is lower than it is for other sexually transmitted viral infections. ${ }^{17}$ However, the role of sexual transmission in the spread of $\mathrm{HCV}$ should not be overlooked and there is need for the general population to be taught on the risk of sexual behaviour.

This finding indicated that participants with no education had the highest seroprevalence of $\mathrm{HCV}$ infection and the least observed in those with secondary education although there was no statistical significant association. This is in disagreement with Pennap et $a l,{ }^{12}$ who reported a significant association between people with no education and HCV infection in Masaka, Nasarawa State. The non-significant association in this study shows that education was not a risk factor in contracting $\mathrm{HCV}$ infections among the participants in this study. However, there is need to create awareness and those confirmed to be positive for $\mathrm{HCV}$ infection should be treated to eradicate or reduce further spread of the infection in the area.

With regards to occupation, $\mathrm{HCV}$ infection was more prevalent among the unemployed and least in public servants. The highest prevalence recorded among the unemployed could be due to hardship and limited income exposing them to risky lifestyles and subsequently the virus. There was no statistically significant association between the viral infection and occupation. This outcome could be related to chance as they are out- patients who emerge from different areas of the country and different works of life. In contrast, studies have earlier reported higher prevalence in participants with other occupations such as $4.2 \%$ among the employed in Makurdi, 38.9\% among the self employed in Ibadan and 1.8\% among farmers in Keffi. ${ }^{34,19,33}$ These variations could be due to differences in lifestyles, tradition and location. ${ }^{25}$

With reference to settlement, subjects from rural areas recorded the highest prevalence of $8.9 \%$ of $\mathrm{HCV}$ infection against $6.3 \%$ observed in those from urban areas. However, this finding was not a statistically significant risk factor to infection. But it disagreed with the work of Pennap et al,,$^{33}$ who reported higher prevalence among the urban participants and least in rural.

Blood transfusion was not a significant risk factor for the acquisition of HCV infection in this study. Those who had a history of blood transfusion have the highest prevalence $(8.4 \%)$ of the viral infection. Similarly, Chinenye et $a l,{ }^{19}$ documented a higher prevalence of HCV among subjects in Ibadan, South Western, Nigeria. This could be as a result of the blood samples not properly screened before transfusion or the virus infection was in the window period when the blood transfusion was done.

A non-significant association was discovered between the viral infections and history of jaundice. Those who had history of jaundice had no prevalence of HCV compare to the people who have no history of jaundice. This is in contrast with studies that have identified contact with persons with jaundice as risk factor to HCV infection. ${ }^{35}$ Similarly, participants with family history of hepatitis have no $\mathrm{HCV}$ infection in contrast with those with history of hepatitis and therefore it is not a possible risk factor for HCV virus among the study population. This is in agreement with the finding of Omolola et al. ${ }^{36}$ who reported that there was no association between family history of hepatitis and the viral infection.

Scarification marks in HCV infections was higher among those with tribal marks and tattoo marks compare to those without it. This shows that tattooing is a factor in the spreading of HCV infection in this study. Secondly, the patients must have been infected through use and sharing of unsterilized sharp objects for their body art. This agrees with a similar study documented in Cote d'voire by Kouassi et $a .^{7}$ Statistically, there was no significant difference between viral infections and scarification marks.

With respect to alcohol intake, the patients who take alcohol had the highest prevalence of $\mathrm{HCV}$ infection than those who do not consume alcohol. Alcohol could lead to progression of HCV infection and viral replication due to overproduction of free radicals that destroy liver cells. ${ }^{37}$ However, history of alcohol 
intake is not a possible risk factor for hepatitis $\mathrm{C}$ virus among the study population. This result disagrees with a study reported by Kawo et $a l,^{38}$ that alcohol intake is associated with $\mathrm{HCV}$ infection.

A seroprevalence of the infection (7.8\%) was found among patients that do not smoke cigarette while those that smoke were not seropositive to HCV. There was no statistically significant association observed between smoking habit and the viral infection. This agrees with the works of Pennap et al, ${ }^{33}$ who reported similar finding in Keffi, Nasarawa State. However, this contradicts the results recorded by Pennap et al, ${ }^{12}$ and Kouassi et $a l^{7}$ among a local community in Keffi and Abidjan, Cote d'voire respectively.

The absence of a significant association between sharing of clothes and HCV infections shows that this material does not aid the transmission of $\mathrm{HCV}$ infections in the study population. This finding agrees with the study documented by Waje $e t a l,{ }^{31}$ that there is no prevalence between sharing of clothes and the viral infection. In this study, the patients that shared clothes among themselves have no evidence of $\mathrm{HCV}$ positivity while those who never share clothes had $\mathrm{HCV}$ infection. Therefore, clothes sharing were not associated with HCV infection among the participants in this study. This confirms the saying that HCV is blood borne. ${ }^{39,40}$

In relation to history of surgery among the subjects, those with previous history of surgery had no evidence of $\mathrm{HCV}$ infection while those without history of surgery had $7.9 \%$ seroprevalence of $\mathrm{HCV}$. No risk factor was associated with history of surgery and the virus. This is not in line with the finding of Omolola et al. ${ }^{36}$ who reported $17.4 \%$ seropositives of HCV among participants who had history of surgery in Ilorin, Nigeria.

\section{Conclusion}

This study revealed a prevalence rate of $7.8 \% \mathrm{HCV}$ infection amongst the patients examined in Niger State. Male participants had a higher prevalence compare to females. Marital status was associated with $\mathrm{HCV}$ infection. The other demographic variables and possible risk factors were not significantly associated with the viral infection.

\section{Recommendation}

HCV infections should be acknowledged as a serious blood borne pathogen and tested for before any blood transfusion is done in health care facilities in the state. The health system should be empowered by government, Charity groups, intervention organizations, non-governmental organizations and religious bodies to carter for all $\mathrm{HCV}$ infected persons medically, socially and to support research in vaccine development. There is a need for more awareness campaigns on the prevention and control of the infection among the population since there is currently no known vaccine or cure for $\mathrm{HCV}$ infection.

\section{Acknowledgements}

We would like to acknowledge the staffs of the five selected hospitals where this work was carried out, who have contributed in various ways to make this research work a reality.

\section{References}

1. Kapoor A, Simmonds P, Scheel TK. Identification of rodent homologs of hepatitis C virus and pegiviruses. Microbiol J 2013; 4 (2): 216-229.

2. Ferri C. "Hcv Syndrome: A Constellation of organ- and non organ specific autoimmune disorders, B-cell non-Hodgkin's lymphoma, and cancer". World J Hepatol 2015;7(3):327-330.

3. Abdelsalam MHE, Mohamed AA, Eldisugi HMH, Khalid MEE, Yasir DHE, Abdelazeem H, HH. Sero-Prevalence of Hepatitis Band Hepatitis C virus infection among Sudanese blood donors. Inter Res J Bas Clin Stud 2016;4:014-017.

4. Tellinghuisen TL, Marcotrigiano J, Rice CM. Structure of the zinc binding domain of an essential component of the hepatitis $\mathrm{C}$ virus replicase. Nat 2005;435(7040):374-379.

5. Parimal HP, Hiral KP, Alka BN. Study of prevalence of hepatitis $C$ virus (HCV) infection in a patients attending tertiary care hospital Valsad, Gujarat, India. Inter J Cur Microbiol App Sci https://doi.org/10.20546/ijcmas.2017.605.312.

6. Van Doorn LJ, Kleter GE, Stuyver L, Maertens G, Brouwer JT, Schalm SW, et al. Sequence analysis of hepatitis $C$ virus genotypes 1 to 5 reveals multiple novels subtypes in the Benelux countries. J Gen Virol 1995;76:1871-1876.

7. Kouassi M, Bengue A, Abdoulaye O, Emile AK, Moussa D, Dosso MA. Very high frequency of Hepatitis $B$ and $C$ virus infections during an active screening campaign in Abidjan. Afri J Microbiol Res 2017;11(1):8-15.

8. Yu ML, Chuang WL, Chuang AS. "Treatment of hronic hepatitis $\mathrm{C}$ in Asia: when East meets West".J Gastroenterol 2004;24(3):336-345.

9. Roman C, Jan S, Renata S, Peter G, Petr D, Vlasta S, et al. Prevalence of Hepatitis $C$ virus in adult population in the Czech Republic 2017; https://doi.org/10.1371/journal.pone.0175525.

10. Suzuki R, Suzuki T, Ishii K, Matsuura Y, Miyamura T. Processing and functions of Hepatitis $C$ virus proteins. Intervirol 2012;42(2-3):145-152.

11. Alter MJ, Kruszon-Moran D, Nainan OV, Mcquillan GM., Gao F, Moyer LA, et al. The prevalence of Hepatitis $C$ virus infection in the United States, 1988 through 1994. New Engl J Med 1999; 341:556-562. 
12. Pennap RG, NUHU II, OTI BV. Prevalence of hepatitis $C$ infections among People attending a voluntary screening centre in Masaka, Nasarawa State, Nigeria. Asian J appl microbiol 2016;3:31-37.

13. Sanaz AG, Mohammad RH, Khosro S, Farhad F, Hamid RB, Seyed AR. Prevalence of Hepatitis $C$ Virus Infection in General Population of Mashhad, Northeastern Iran.Iran J Pub Hea 2017; 46(3):408-413. PMCID: PMC5395537.

14. Esperance U, Fabien N, John K, Naomi M. Prevalence of Hepatitis $C$ virus infection and its risk factors among patients attending Rwanda military hospital, Rwanda. BioMed Res Inter 2017;7. https://doi.org/10.1155/2017/5841272.

15. Onakewhor JU, Okonofua FE. Seroprevalence of Hepatitis $C$ viral antibodies in pregnancy in a tertiary health facility in Nigeria. Nigeria Journal Clinical Practice 2009;12:65-73.

16. Nwankiti OO, Ndako JA, Echeonwu GO, Olabode AO, Nwosuh CI, Onovoh EM, et al. Hepatitis $C$ virus infection in apparentenly healthy individuals with family history of diabetes in Vom, Plateau State Nigeria. Virol J 2009;6:110.

17. Onyekwere CA, Ogbera AO, Dada AO, Adeleye OO, Dosunmu AO, Akinbami AA, et al. Hepatitis $C$ virus prevalence in special populations and associated risk factors: A report from a tertiary hospital. Hepathol Mon J 2016;16(5): e35532.

18. Balogun TM, Emmanuel S, Wright KO. Hepatitis $C$ virus co infection in HIV positive patients. Nig Q J Hosp Med 2010;20:117-120.

19. Chinenye GA, Victor UN, Adeola F. Hepatitis $C$ virus among pregnant women in Ibadan, Nigeria: Prevalence, correlates and co-infections with HIV. Inter J Trop Dis Hea 2016;14:1-11.

20. Babatope IO, Inyang NJ, Imhanrevezo K. Aghahowa A. Seroprevalence of Hepatitis ( $B$ and $C$ ) viruses among apparently healthy adult in Ekpoma, Edo State, Nigeria. Spe Vir Path J 2015;1:0015-0020.

21. Isa MA, Muhammad UK, Manga SB, Magga HK. Prevalence of anti-Hepatitis $C$ Virus antibodies among patients attending Sokoto specialist hospital Sokoto, Nigeria. J Appl Sci Res 2014;1(4):261-266.

22. Cheesbrough M. Laboratory practice in tropical countries part II. Cambridge University press, Cambridge, United Kingdom. 2002, P. 453.

23. Mohammed HK, Groeger J, Flaxman ST, Wiersma ST. Global Epidemiology of Hepatitis $C$ infections: new estimates of age specific antibody to HCV. CDC: 2015 Hepatol 2013;57(4):13331342.

24. http://wwwnc.cdc.gov/travel/yellowbook/2016/infectiousdiseases - related-to travel/hepatitis-C. (Accessed date: Nov 2015.

25. Zacchaeus AJ, Baribefe E, Fiekumo B, Felix E. Prevalence of antibodies to Hepatitis $C$ virus in apparently healthy Port Harcourt blood donors and association with blood groups and other risk indicators. J blo transf 2008;6:150-155. doi: 10.2450/2008.0053-07.

26. Isa MA, Emeka A, Aisha MA. Serological evidence of Hepatitis $C$ virus antibodies among students attending University of Maiduguri Medical Centre, Borno State, Nigeria. Inter J Adv Res Biol Sci 2016; 3: 6.

27. Janet UI (2017). Prevalence of Hepatitis $B$ and $C$ in Jos, Plateau State, Nigeria. J Antivir Antiretro 2017; 9: 3. (Suppl) DOI: 10.4172/1948-5964-C1-036.

28. Sheyin Z1, Jatau ED, Mamman AI, Randawa AJ. Molecular epidemiology of Hepatitis $C$ virus in kaduna State. Afri J Cli Exp Microbiol 2012; 13(2): 61-65.
29. Bigwan EI, Jatau ED, Inabo HI, Ado SA. Seroprevalence of Hepatitis $C$ virus amongst blood donors in parts of north central Nigeria. Brit Microbiol Res J 2016;15:1-6. DOI: 10.9734/BMRJ/2016/26530.

30. Tula MY, Iyoha O, Okpalauwaekwe EA, Mohammed A, Iruolaje FO, Okpara AN. Seroprevalence of Hepatitis B surface antigen (HBsAg) and Hepatitis $C$ virus(HCV) co-infection among apparently healthy students of a tertiary institution in northeastern Nigeria. Nig J Microbiol 2016;30(2):3565-3571.

31. Waje T, Dadah JA, Muhammad Y, Orukotan A., Ladan Z. Prevalence of Hepatitis $C$ infections among the outpatient population of selected hospitals within Kaduna city, Nigeria. World J Pub Heal 2016;1:33-44. doi: 10.11648/j.phi.20160101.16.

32. Abiodun CJ, Bolaji OO, Sebastine OO. Prevalence of Hepatitis $C$ virus antibody among undergraduates in Ogbomoso, Southwestern Nigeria._Afr J Infect Dis 2014;8:40-43.

33. Pennap RG, Oti BV, Alaribe AG, Ajegena SA, Galleh PR. Seroprevalence of hepatitis $\mathrm{B}$ and $\mathrm{C}$ viruses among human immunodeficiency virus infected patients accessing healthcare in Federal Medical Centre, Keffi, Nigeria. J Adv Microbiol 2017;3:1-6.

34. Godwin IA, Abraham OM, Peter TM, Terkaa TB, Vivian NS, Hameed M, et al. Prevalence of Hepatitis $C$ in Makurdi, North Central Nigeria. J Dent Med Sci 2013;7:6-10.

35. Agarry OO, Lekwot GZ. Prevalence of Hepatitis $B$ virus and Hepatitis $C$ virus in ante-natal patients in Gwagwalada- Abuja, Nigeria. Report and Opinion 2010;2(7):48-50.

36. Omolola BO, Kikelomo TA, Abayomi F, Gbenga P. Hepatitis $C$ virus seroprevalence, antigenaemia and associated risk factors among pregnant women in Nigeria. Ethiop Med J 2015;53:No. 4.

37. Collins S, Swan T. Guide to Hepatitis C for people living with HIV: testing, co-infection, treatment, and support. Treatment Action Group. New York, New York. 2009.

38. Kawo AH, Bala JA, Dabai YU. Sero-prevalence study of Hepatitis $C$ virus infection among blood donors attending selected blood banks in some Local Government Areas in Kano, Nigeria. J Pub Heal Epidemiol 2012;4(6):178-183.

39. Ejiofor OS, Emechebe GO, Igwe WC, Ifeadike CO, Ubajaka CF. Hepatitis $C$ virus infection in Nigerians. Nig Med J 2010;51(4),173-176.

40. Centers for Disease Control and Prevention. Hepatitis C. U. S. Department of Health and Human Services. http://www.cdc.gov/hepatitis. 2 Accessed 3rd Sept., 2013. 